\title{
Improving the Effectiveness and Demand for Educational Programs in Financial Technologies
}

\author{
Alexander A. Tsyganov ${ }^{1}$, Sergey V. Brovchak ${ }^{2}$, Yulia A. Gorelova ${ }^{3}$, Lyubov S. Krutova ${ }^{4}$, \\ and Marina A. Selivanova ${ }^{1}$ \\ ${ }^{1}$ Financial University under the Government of The Russian Federation, Department of Insurance and \\ Social Economy, Moscow, Russia \\ ${ }^{2}$ Financial University under the Government of the Russian Federation, Association of financial \\ market participants «Council for professional qualifications of the financial market», Department of \\ Insurance and Social Economy, Moscow, Russia \\ ${ }^{3}$ FinTech Association, Moscow, Russia \\ ${ }^{4}$ Financial University under the Government of the Russian Federation, Mortgage Housing Lending \\ and Financial Instruments of The Real Estate Market Department, Moscow, Russia
}

\begin{abstract}
The research purpose is to develop proposals for improving the quality of education in the field of innovative financial technologies.Methods. The following methods were used in the research: theoretical methods, including review and analytical study, comparison and generalization methods, as well as empirical methods, such as expert assessments (questionnaire survey), and statistical methods (statistical observation). Conclusion. Analyzing the respondents' assessment, the data were obtained that allowed revealing that in practice, the development of the labor market associated with digitalization faced certain problems. In particular, it was revealed that, despite the potential value of improving the quality of education in the field of financial technologies, increasing the level of knowledge and competencies, there was a problem associated with reducing jobs, which in turn increased an opportunity for developing the labor market. Based on the results obtained, conclusions were formulated demonstrating the relationship between the quality of training of labor forces and innovative changes in the economy within the educational process and educational programs.
\end{abstract}

\section{Introduction}

Currently, society and the economy are undergoing significant changes associated with the post-industrial stage of development, and the significant advancement of innovative technologies. In the nearest future, the development of fundamental and practical scientific research based on the creation of innovation hubs that would support startups in the digital economy should become the core process [1].

Due to the current situation, the global economy is not going through the best of times. The crisis has not spared a single industry. Nevertheless, the introduction of quarantine

\footnotetext{
* Corresponding author: tsyganov@list.ru
} 
measures and restrictions on the movement of citizens by several countries, including Russia, encourages new opportunities for the growth of new financial services. According to a study by the deVere Group consulting company, due to the measures taken by the authorities in the fight against coronavirus, European residents have become $72 \%$ more likely to use FinTech applications for money transfers, insurance, virtual cards and digital moneyboxes [2].

The most popular FinTech services in Russia are money transfers and payments. Banks use this industry product in other areas, including education. For example, biometric identification, Open APIs (Application Programmer Interface), artificial intelligence (AI), machine learning, and automation of routine processes.

Every third resident of cities with over one million uses more than two FinTech services daily on average. Russia is one of the world leaders in the penetration of FinTech services with a level of $82 \%$, significantly exceeding the global figure, ranking after China and India. Compared to 2017, the index has almost doubled (from 43\% in 2017 to $50 \%$ in 2018) [3].

However, the education system, being inherently conservative, lags behind the needs of the FinTech services market and can become a deterrent to development.

The development of Russian FinTech is hindered by the closed nature of higher education institutions, which are both a base for training students in this field, and a laboratory for creating a new FinTech product. Many promising university developments do not go out into the world. Universities state that they can find customers themselves and therefore do not need the services of accelerators. But it often turns out that university chairs do not understand not only to whom and how to offer their in-house developments, but not always can find cases for practical application of laboratory developments. According to researchers [4-5], this is also related to the problem of training professional personnel, namely, the isolation of the educational program from the business needs.

According to studies by foreign scientists [6-11], research on the problems of training specialists and their demand in the labor market in the FinTech area is relevant and significant in terms of practice.

The problem of the study is that the global economy, including the Russian economy, is currently facing a new challenge, namely, a coronavirus pandemic. This raises the issue of the lack of highly qualified personnel in the field of innovative financial technologies, and thus their training within the framework of standardized requirements is an important task to be solved in this article. Besides, the research aims at obtaining data that would allow developing a strategy for training specialists with special competencies related to the elaboration and promotion of financial products based on contemporary technologies and justifying the need to implement an independent assessment of the formed qualifications in the educational process.

\section{Methods}

Taking into account the short period of implementation of educational programs in Russian universities, differences in the organization and content of the teaching process in technical and economic universities, it is necessary to have uniform requirements for the new specialization and profession directly related to FinTech. To describe a new profession/specialty, "the effectiveness of the type of professional activity should be evaluated as achieving the necessary results at an acceptable time, financial, and labor costs" [12-15].

The assumption that more formalization and clarification of requirements for the content of special knowledge and competencies formed in the course of training are required, corresponds to the recognition of a new profession - a specialist in innovative financial technologies. This assumption was confirmed by a representative survey of students from several Russian universities, and conjunctural survey of representatives of member 
companies of the Association for Financial Technology (FinTech Association) ${ }^{\dagger}$, as well as analysis of educational programs of leading Russian financial and economic universities.

The survey involved students of the Financial University under the Government of the Russian Federation, specializing in economics, namely, in majors: "Finance and credit", "Economic security", "State financial control", as well as members of the International Association of Economic and Financial Education of the Financial University under the Government of the Russian Federation. The survey was conducted in the fall and winter of 2019 using questionnaires provided by [16].

The survey has shown that $72.9 \%$ of respondents believed that it was necessary to include the course of practical use of financial technologies in the professional sphere as a mandatory subject in the educational program, $22 \%$ - found it difficult to answer, while $5.1 \%$ did not see this as necessary.

The survey participants have identified the following trends (problems) in the development of the labor market related to digitalization:

1)job cuts that will lead to unemployment;

2)the demand for information technology specialists will increase;

3)automation of management processes requires new skills and abilities;

4)increasing demand for information security specialists;

5)the emergence of new professions, replacing routine work;

6)the emergence of continuous learning including distance learning;

7)qualified specialists with advanced financial analysis tools are very valuable;

All respondents believe that companies need to implement digital services, explaining this for various reasons, such as ensuring high rates and quality of work; simplifying processes and avoiding the routine work that artificial intelligence can do for them; optimizing and rationalizing production processes; improving efficiency; improving the lives of the population; reducing bureaucracy and increasing the speed of decision-making; improving competitiveness, etc.

\section{Results}

The majority of students surveyed had a clear understanding of the importance and necessity of knowledge in contemporary financial technologies.

Despite almost $100 \%$ coverage of Russian youth with digital gadgets and computerization of education [17], students themselves do not believe that they have fully formed digital competencies sufficient for successful use at work. Only 53\% of students who participated in the survey believed that they did not have serious gaps in digital skills, while $35 \%$ noted the existence of certain problems in this area. At the same time, $71.2 \%$ of respondents noted that they were not concerned at all about working in a technically saturated environment, while $15.3 \%$ found it difficult to answer.

During the survey, students were allowed to express their opinions on trends and problems in the development of the labor market related to digitalization. The survey participants identified the following factors and consequences of their implementation (Table $1)$ :

\footnotetext{
$\dagger$ The Association for Financial Technology (FinTech Association) was established at the end of 2016 on the initiative of the Bank of Russia and key players of the domestic financial market; it includes 32 organizations (including banks, insurance companies, telecommunications companies, and payment companies).
} 
Table 1. Trends and problems in the development of the labor market related to digitalization, according to the surveyed students [18]

\begin{tabular}{|c|c|c|c|}
\hline \multicolumn{2}{|c|}{$\begin{array}{l}\text { Trends and problems in the } \\
\text { development of the labor market } \\
\text { related to digitalization }\end{array}$} & $\begin{array}{l}\text { Required knowledge and } \\
\text { skills }\end{array}$ & $\begin{array}{l}\text { Possible cyber threats and } \\
\text { risks }\end{array}$ \\
\hline 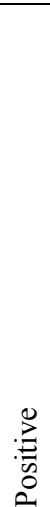 & $\begin{array}{l}\checkmark \text { increasing the demand } \\
\text { for information technology } \\
\text { specialists; } \\
\checkmark \quad \text { increasing the demand } \\
\text { for information security } \\
\text { specialists; } \\
\checkmark \quad \text { replacing routine work; } \\
\checkmark \quad \text { increasing the value of } \\
\text { qualified specialists possessing } \\
\text { contemporary financial } \\
\text { analytics tools; } \\
\checkmark \quad \text { hunting for creative and } \\
\text { thinking employees }\end{array}$ & \multirow{3}{*}{$\begin{array}{l}\checkmark \quad \text { knowledge of the } \\
\text { programming basics; } \\
\checkmark \quad \text { ability to forecast } \\
\text { and analyze; } \\
\checkmark \text { advanced } \\
\text { knowledge of digital } \\
\text { services and } \\
\text { technologies; } \\
\checkmark \quad \text { ability to learn new } \\
\text { things and improve skills; } \\
\checkmark \quad \text { ability to work with } \\
\text { big data; } \\
\checkmark \quad \text { developing } \\
\text { existing skills and } \\
\text { improving them; } \\
\checkmark \quad \text { ability to quickly } \\
\text { navigate when searching } \\
\text { for information of } \\
\text { interest, work with } \\
\text { specialized software and } \\
\text { knowledge of English; } \\
\checkmark \quad \text { knowledge of } \\
\text { practical use of financial } \\
\text { technologies, etc. }\end{array}$} & \multirow[t]{3}{*}{$\begin{array}{l}\checkmark \quad \text { psychological } \\
\text { dependence of a person on } \\
\text { gadgets; } \\
\checkmark \quad \text { the loss of a person's } \\
\text { skills because all the work } \\
\text { will be performed by } \\
\text { automatically configured } \\
\text { mechanisms; } \\
\checkmark \quad \text { staff reduction; } \\
\checkmark \quad \text { financial risk; } \\
\checkmark \quad \text { risk of hacking data of } \\
\text { citizens and companies; } \\
\checkmark \quad \text { information leak to } \\
\text { competitors; } \\
\checkmark \quad \text { war with robots, etc. }\end{array}$} \\
\hline 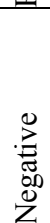 & $\begin{array}{l}\checkmark \text { job cuts that will lead to } \\
\text { unemployment; } \\
\checkmark \quad \text { the disappearance of } \\
\text { many professions due to the } \\
\text { implementation of artificial } \\
\text { intelligence }\end{array}$ & & \\
\hline 恶 & $\begin{array}{l}\checkmark \text { possessing new skills and } \\
\text { abilities, as well as management } \\
\text { processes automation are } \\
\text { required; } \\
\checkmark \text { high requirements for } \\
\text { specialists; } \\
\checkmark \text { the emergence of new } \\
\text { professions; } \\
\checkmark \text { programming skills will } \\
\text { be in demand; } \\
\checkmark \text { the emergence of } \\
\text { continuous, including distance } \\
\text { learning. }\end{array}$ & & \\
\hline
\end{tabular}

Note: The Table combines similar answers; the text was processed while preserving the style of the respondents

Thus, the above survey allows concluding the obvious insufficiency of the implemented educational process to meet the needs of employers in quality labor resources in the FinTech area. At present, employers' expectations are seriously at odds with students' ideas about their future profession [19].

\section{Discussion}

As a result, the authors of the research have proved that Russia has not yet created a sufficient specialist training system suitable to participate in innovative economic processes. It is important to take into account the characteristics of the type of professional activity as a list of related functional processes within the framework of achieving a single goal defined by legislation, differing from each other by the legal and regulatory regime, as well as the content of tasks and qualification requirements. 
A qualified workforce that is trained by the education system and able to develop based on cognitive skills according to innovative changes in the economy within the framework of highly effective state programs is the basis of sustainable development [20]..

\section{Conclusion}

Based on the results of the analysis of the above-mentioned empirical research, it seems necessary to conduct a comprehensive content analysis of federal state educational standards and general educational programs in terms of competencies required by the market.

Special competencies for specialists in the FinTech area, as well as the content of their professional activities, should be determined by the professional standard "Specialist in innovative financial technologies", which will allow achieving a common understanding of the work specifics of such specialists, and form the necessary competencies to organize the effective pedagogical process for teachers and, accordingly, graduates of Russian universities.

\section{References}

1. M.A. Selivanova, D.A. Tyunin, M.M. Bogdanova, Financial business 6(197), 27-32 (2018)

2. Innovation trends: what happened during the week from April 13 to 17, 2020 Available at: https://www.rbc.ru/trends/innovation/5e99dd089a794716b7e9401f

3. Private financial technologies as a tool for sustainable business development in Russia and Kazakhstan. Trends in the financial technology market (Deloitte CIS Research Center, 2018) Available at: https://www2.deloitte.com/ru/en/pages/researchcenter/articles/chastnye-finansovye-tekhnologii-kak-instrument-ustojchivogo-razvitiyabiznesa-rossii-kazahstane.html

4. N.V. Kirillova, T.A. Belousova, Y.V. Gryzenkova, V.S. Vasyakin, E.L. Pozharskaya, Eurasian Journal of biosciences 113(1), 141-148 (2019)

5. A.A. Tsyganov, Prospects for science and education 5(41), 130-146 (2019)

6. I. Okhrimenko, A. Lukyanova, I. Sovik, S. Pyankova, Espacios 40(38), 26 (2019)

7. J. Liu, X. Li, S. Wang, Technological Forecasting and Social Change 155 (2020)

8. H. Sun, D.C.Y. Yuen, J. Zhang, X. Zhang, Research in International Business and Finance 52 (2020)

9. V. Frisancho, Economics of Education Review 101918 (2019).

10. W.J. Jacob, V. Gokbel, International Journal of Educational Development 58, 5-17 (2018)

11. E. Colombo, F. Mercorio, M. Mezzanzanica, Information Economics and Policy 47, 2737 (2019)

12. S. V. Brovchak, Entrepreneur's Guide 41, 64-71 (2018)

13. S. V. Brovchak. Professional standards for specialists in the field of compulsory social insurance, Educational Programs and Professional Standards: Search for Effective Interaction: Collection of materials based on the results of the International Scientific and Practical Conference, Moscow, Russia (2016)

14. S. V. Brovchak, A. A. Tsyganov, Financial business 3(200), 45-50 (2019)

15. A. A. Tsyganov, A. S. Ermolaeva, S. V. Brovchak, E. V. Bogdanova, Prospects for science and education 5(41), 517-528 (2019) 
16. International Association of Financial and Economic Education Organizations Available at: https://maofeo.com/

17. S.V. Butsyk, Open Education 23(1), 27-33 (2019)

18. Laboratory of online learning and data analysis in education of the Financial University Available at: http://www.fa.ru/org/faculty/ioo/lab/Pages/Home.aspx

19. A.A. Tsyganov, N.V. Kirillova, E.V. Kamneva, Modern Journal of Language teaching methods 8(12), 995-1105 (2018)

20. The role of professional qualifications boards in developing professional standards will increase Available at: http://nspkrf.ru/news-nspk/item/165-nspkrf-37.html 